DOI https://doi.org/10.18551/rjoas.2017-10.20

\title{
SOCIO-ECONOMIC STUDY OF SUPLIT STONE BREAKER WOMEN IN SUPPORTING FAMILY LIFE: A CASE STUDY OF INFORMAL SECTOR STONE BREAKER WORKER IN THE NORTH MORAMO, INDONESIA
}

\author{
Kambolong Makmur*, Sahrun \\ Faculty of Administrative Science, University of Halu Oleo, Indonesia \\ *E-mail: h.makmurkambolong@gmail.com
}

\begin{abstract}
A socio-economic study of Suplit Stone breaker women In Supporting Family life is a study of the Informal Sector Workers carried out in the form of a survey. This study aims to assess the socio-economic level of the workers, educational level, results achieved, income levels, health effects, and household's social condition. This research will specifically study and analyze income received, identify and examine the issues that arise in performing stone breaker as an occupation: deficiencies, expectations, and negative impacts. Ten urban villages/villages in Moramo North District was taken as research population. Area samples taken were five (5) urban/rural where workers are concentrated in Lalowaru Village, Puasana Village, Mata Mawatu Village, Sanggula Village, and Lamokula Village. Samples community were 5 percent of all household. Therefore total samples taken were 93 people scattered in villages. Research informants are Head of North Morano district, Stone Processing owner, and stone carrier driver. Data collection was conducted by observation, interview using a list of questions, as well as documentation of objective conditions. Data were analyzed using descriptive analysis techniques, which describe the objective conditions of the field in accordance with the purpose of research. Research result shows workers are housewives who help their husbands and families to supplement the household income to support family life. In general, socio-economic conditions of women suplit stone breaker is relatively low, their education level is generally elementary or none. The results achieved are still limited by an average of IDR 30,000 , per day/worker is calculated based on the total stone yield. These women perform their work using simple tools such as hammer and gloves. The negative impact on eye health and breathing difficulty caused by inhaling stone dust every day. The problems faced by the workers is the lack of working capital to be trying to own the business processes, the impact on the health of the eye and breathing for workers. Income received by workers can be used to meet the basic needs level, therefore, obtained income can be used to support family life.
\end{abstract}

\section{KEY WORDS}

Socio-economic status, informal sector, stone breaker, women.

Labor issues are in conjunction with urbanization, migration, and work structure. It is a popular topic discussed by scientists since the 1970s. Afterwards, there are several studies emerging which highlight labor issues, particularly in the Third World.

"Classic" Arthur Lewis, proposes a number of models and theories on economic development, on the assumption that labor in the countryside is the main capital of urban areas construction industry. This theory cannot be justified from third-world experiences. American sociologist Hozelitz explained that it is "urbanization without industrialization". McGee, referred to such phenomenon as the "urbanization pseudo", because of urban development is not accompanied by economic growth rates fast enough to provide jobs for the growing city population. This is due to the application of capital-intensive technology in the industrial sector in city region and "urban bias" (tendency to give priority to the city), as well as the development policies in the third world, tends to ignore the rural areas (Manning and Effendi, 1991).

A number of urban development does not emphasize physical urban economic aspects, therefore problems faced by the urban poor working in the informal sector is less 
managed. The new paradigm in urban development is to speed up managing urbanization problem and "institutional radicalization". Returning to the roots of institutional grow within the community itself, which concerns the economic institutions, and aids urban poor working in informal sector (Mabogunje, 1991),

World Bank suggested on urban problems coping strategies, that the productivity of the poor urban population should be improved by increasing the demand for labor and improving their access to basic infrastructure and social services (Poli, 1993).

Economy expert generally believes that rapid economic growth will be accompanied by changes economy structure. Industry and services sector roles are growing and the relative role of the agricultural sector decreased. This structural change will be reflected also in the deployment of the labor sector. Those working in agricultural sectors declined not only in relative but also in absolute. Industrial and services sectors absorb labor market in relative and absolute manner.

Indonesia's economic growth for almost a decade and a half exhibits point of interest. While the economy grew rapidly, employment phenomenon has not experienced significant structural change (improvement). Judging from the composition of the gross domestic product, agricultural sector role declines. Followed by the relative proportional decline of the population employed in the agricultural sector. On the other hand, the macro indicators exhibited improved employment (Squire, 1986).

Residents of urban areas are increasing rapidly due to two reasons: first, because the birth rate is higher than the death rate. Secondly, due to urbanization. City population growth is not matched by employment, would lead to unemployment and underemployment. It is the main cause of the informal sector. As stated by Wirutomo (1994). Informal sector (which means all-primitive) in a global economy field are still considered relevant. This sector is required to fulfill third world population needs.

With regard to the explanations of the theory as research result and assessment experts, this research is related to the informal/traditional sector. Study subjects were women stone crushers who breaks suplit mountain stones into several sizes. According to initial survey result on several locations in the community and Local Government (District Head and village chief, September 20, 2017), this particular research has not been conducted in the selected research area.

The informal sector or the traditional sector in South Konawe, particularly in North Moramo district, there is more informal/traditional sector compared to other areas. Especially informal/ traditional sector in cast concrete manufacture and similar product. Those working in suplit stone breaking informal sector are generally housewives or women in school-age or another member of the social class.

Based on the conceptual background, the research problem is formulated as the following description:

1. How are the socio-economic conditions of women workers suplit stone-crushing North Moramo South Konawe?

2. How big an acceptable income level as a suplit stone breaker suplit?

3. What are the problems faced by women workers to perform as suplit rock breaker?

\section{REVIEW OF LITERATURE}

"Classic" Arthur Lewis offers a number of models and theories on economic development on the assumption that labor in the countryside is the main capital of urban areas construction industry. Indonesia's economic growth for almost a decade and a half shows an interesting phenomenon. This is due to a various phenomenon occurring. While the economy is growing rapidly, labor had no significant structural changes.

Due to limited formal sector capacity caused social structure and mobility between sectors to absorb labor force runs comparatively very slow compared to economic growth. It ultimately leads to distortion in the pattern, activity type, employment, work hour as well as macro characteristics of other employment. 
Wirutomo (2004) questions the present informal sector in the economy sector globally. The informal sector is still required to fulfill third world population need.

According to François Valentijn (in Candrakirana, 1995: 2) activities as proposed in the informal economy since Batavia (Jakarta) 1724. At that time hawkers carried sorts of goods traded in the streets. They sell an assortment of vegetables, porcelain, fabrics, handicrafts, tea, bread, water, flower, used clothing, socks and others. Such sales practice had been previously banned by the VOC. The ban was lifted at 1739 .

Simanjuntak (1995: 98-99) provides characteristics of the informal sector which are classified as follows:

a. Business activities are generally simple;

b. The relatively small scale of business;

c. Informal sector enterprises generally do not have a business license;

d.Obtain work in the informal sector more easily than in the formal sector.

Hans Singer (in Chandrakirana, 1995: 16) explains that informal sector is similar to giraffes, it has undistinguished shape but recognizable once one gaze upon it. Dipak Mazundar (in Manning and Effendi, 1996: 12) defines informal sector as an unprotected labor market. One important difference between formal and informal sector is informal sector is riddled with unfixed working hours. This is caused by the absence of long-term employment contract relationship in the informal sector and wages tend to be calculated per day or per hour as well as the prominence of independent business. Jan Breman (in Manning and Effendi, 1996: 139), without specifying the clear terms but distinguishes formal and informal sectors are pointing to an economic sector each with its own consistency and structure dynamics. The formal sector is used in the sense of daily wage workers or permanent work which include:

a. A number of interrelated work that is part of a structure of the interwoven job and very organized;

b. Work is officially registered in the economic statistics.

De Soto (1992) suggests that division of economic activities into the formal sector and the informal sector will have a bad influence on the State's economy in general. Consequences arising is subject to decreased productivity, decreased capital investment, inefficient tax system, public service rates increase, undeveloped technology level, and a number of difficulties hamper the preparation of the State's economic policies.

Furthermore, De Soto said there are two things at the informal activities that result in a decreased capital investment. First, informal entrepreneurs use more labor intensive technology, because business as economic institutions tends to move towards the informal sector. Second, given the difficulties faced by informal employers to ensure that the contract is not violated, and the high interest they have to pay when they borrow money on the capital providers. There will be a lot of long-term investments for production. Capital investment also dropped due to the high costs in the informal sector.

Manning and Effendi (1991) suggest that some economy expert and government representatives believe that more resources, better processing, and stronger informal sector growth, the city can provide a better life to its citizens, including the workers in the informal sector.

Sethuraman (1991) suggests that the term "informal sector" is usually used to indicate a number of small-scale economic activities. But it would be misleading to so-called "business" small scale, for several reasons. The informal sector is regarded as a manifestation of the situation of employment growth in the developing countries, mainly aims to seek employment and income rather than profit. Those involved in this sector are generally poor, low-educated, unskilled, and mostly immigrants.

In other words, the informal sector in the city, especially seen as units of small-scale involved in the production and industrial goods are still in a process of evolution rather than regarded as a group of small-scale companies with big capital and management (managerial) input.

The existence of the informal sector cannot be separated from the development process. There are two ideas that flourish in understanding the link between development 
and the informal sector. First, thought process stating that the presence of the informal sector as a symptom of a transition in the development process in the developing countries. The informal sector is the stage that must be passed on to the modern stage. This view argues that the informal sector would gradually evolve into a formal sector with increasing development. It means that the existence of the informal sector is a temporary phenomenon and will be corrected by development success.

Second, thought processes that argued the informal sector is a symptom of an imbalance in development policy. The presence of the informal sector is seen as a result of development policy which in many cases are more severe in the modern sector (urban) or industry than the traditional sector (agriculture). The informal sector will continue to be present in the development process while the traditional sector is not progressing. Further adherents of this view argue that the development of the informal sector depends on the attitudes of development policies. During its development policies tend to favor the modern sector and the traditional sector is only seen as a provider of raw materials for the modern sector as well as their attitude of "sacrifice" of the traditional sector, the informal sector will remain and are likely to increase.

\section{METHODS OF RESEARCH}

This study is a descriptive study, the research illustrates the current state based on the facts, therefore method used in this study is a survey method in order to describe the conditions of informal sector workers as stone breakers.

Research Variables. Variables defined in this study concerning the socio-economic problems of the workers as stone breakers, among other things are age, education, status in the household, production result, income received, the work system, wage system, reasons that pushed to engage in such business, health, the perceived negative impacts, issues, and expectations.

Sample Determination and Collection Technique. Results initial survey exhibits that there's uncertainty on a total number of women were involved as stone crushers, these women are spread in 10 urban villages/villages in North Moramo South Konawe (Results interview North Moramo District, September $29^{\text {th }}, 2016$ ).

For the purpose of sampling, researchers set 5 regions out of 10 urban villages considering its concentrated number of stone workers in North Moramo. The villages involved were 1) Lalowaru Village, 2) Wawatu Village, 3) Mata Wawatu Village, 4) Sanggula Village, and 5) Lamokula Village.

Since there is no definite figures and number of stone worker relatively homogenous data, then the determination of the sample size was set at $10 \%$ of the number of families in each region/village sample. There were 93 samples taken. Determining workers sample used random sampling.

Data Collection Technique. To collect a wide range of primary and secondary data, researchers used the following data collection techniques:

1. Questionnaires/list of questions. Data collection through the dissemination of the list of questions (questionnaire) which are open nature and there's no predetermined answer, each respondent answer prepared questions.

2. Interviews. Interviews were conducted on informants, such as Head of District, the Village Head, Community Leaders, Stone Entrepreneurs/Businessmen, stone transporter driver. This activity aims to obtain additional data or confirm the results of the data obtained from the workers.

3. The document, i.e the data regarding the condition of the area in general, either geographical data, demographic, social, cultural and economic condition of the North Moramo district.

Data Analysis Techniques. Data analysis techniques used is descriptive analysis, which is a form of analysis that describes conditions of the study object in accordance with the purpose of research. The results of this study are presented in the form of frequency tables, percentages, and provide recommendations on the parties which is competent in 
dealing with stone-crushing workers as informal sector enterprises to the family economy in particular, and the region's economy in general.

\section{RESULTS AND DISCUSSION}

Social condition. The social conditions intended in the study are objectively stated about the family circumstances which may be studied and analyzed in relation to work and income in aiding family economic life. Discussion on family social conditions, is related to their family members. Those aspects are children, tuition fees, house status, and house condition.

Family members. Family member associated with work and incomes. Received income will be used for daily need cost, especially for children's school tuition fee. The results exhibit the degree of variation in the number of children. The respondent families have been grouped into several categories as presented in Table 1.

Table 1 - Respondents by Number of Family Members 2017

\begin{tabular}{|c|c|c|c|}
\hline Number & Family Member & Number & Percentage \\
\hline 1 & $\leq 2$ & 3 & 3.22 \\
\hline 2 & $3-5$ & 70 & 75.27 \\
\hline 3 & $\geq 6$ & 20 & 21.51 \\
\hline \multicolumn{2}{|c|}{ Total } & 93 & 100.00 \\
\hline
\end{tabular}

Source: processed questionnaire.

Table 1 exhibits a number of workers family member. These workers generally have a large family, which is between 3 to 5 members $(75.27 \%$ of all respondents). There are workers having 6 or more family members. These facts prove that the family's head burden is heavy, so it is reasonable if the workers (mothers) participated working to ease the burden on their husbands as family heads obliged to bear the economic life of theirs.

This research also examined a number of children the workers have. The number of children will affect family life as children require education expenses. Ultimately it requires mothers to work hard to earn money to meet the children's need/schooling expense. The details of respondents' number of children are presented in Table 2.

Table 2 - Respondents by Number of Children 2017

\begin{tabular}{|c|c|c|c|}
\hline Number & Children's & Number & Percentage \\
\hline 1 & $\leq 2$ & 45 & 48.39 \\
2 & $3-5$ & 42 & 45.16 \\
3 & $\geq 6$ & 6 & 6.45 \\
\hline & & 93 & 100.00 \\
\hline
\end{tabular}

Source: processed questionnaire.

The table above exhibits a number of children as a family burden. Respondents having 2 children were $48.39 \%$ out of total respondents. Respondents having 3 to 5 people were $45.16 \%$. Therefore mothers/housewives endeavor to find a job and work in order to increase household economy.

House Status. Direct field research results showed that all respondents possess their own housing. No respondents come to work specifically to rent a house. Respondents are generally native citizens who have hereditary life and make a living in the Moramo District, where they already have their own home as a residence.

House Shape/Condition. Respondent's home form is generally still semi-permanent, meaning that not all the walls of their houses are made of stone. On the other hand the respondents possessing permanent house are still burdened with shortcomings, such as not having glass windows.

Economic Conditions. Economic conditions meant is to determine and explain things related to workers lives. Economic conditions will be discussed in the general level of 
earnings/income from work per day / per month, number of suplit stones produced, wage/salary system, suplit stone size generated, sale system, and the statement about the job that can support family economically.

Income level. The results showed earned income as stone crushers for suplit stone manufacturing. More details categories amount of income received, as shown in Table 3.

Table 3 - Respondents Daily Income 2017

\begin{tabular}{|c|c|c|c|}
\hline No. & Revenues (US\$) & Amount & Percentage \\
\hline 1 & $10-20$ & 9 & 9.68 \\
2 & $25-30$ & 51 & 54.84 \\
3 & $\geq 35$ & 33 & 35.48 \\
\hline \multicolumn{2}{|c|}{} & 93 & 100.00 \\
\hline
\end{tabular}

Source of data: processed questionnaire.

The table shows the respondents' income levels which are grouped into three categories. Generally, respondents receive 25-30 thousand per day, meaning that respondents earn revenue based on a number of stone produced. The level of income means that each respondent produced suplit stone in the size of $2 \times 1 \mathrm{~cm}$ as much as 5 to 6 arco (the measure used). The workers are paid each acro submitted at an average of IDR 5,000 , -

Each worker receives revenue between IDR 750.000 to IDR 900.000 each month. This sum relatively can be used to gain additional daily needs. Furthermore, there are respondents who earn IDR 35.000 up to 50.000 per day. The respondents worked from early morning until late afternoon with a little break to obtain more result and income within the time allotted. Respondents are relatively young therefore they are capable to work full time.

Stone Productionю Production referred to the amount of mountain stone made into suplit stone. Based on the foregoing discussion that a number of revenues received based on the suplit stone produced. Based on the research result, a number of suplit stone produced is at least 2 (two) arco each worker, and most can reach 8 even be up to 10 Arco per day. With this level of production, it could be inferred respondents took this occupation as primary job support family life/economy. These women are working seriously to break more stones each day.

Salary/Wage System. Salary or income they receive is paid based on the number of stones produced. Produced stone is measured using arco as a tool to measure salaries/wages. As previously noted, the calculation is IDR 5,000 up to IDR 6,000/arco. The payment system is in the form of direct cash paid for buyers (employers truck) who are ready to transport the stone to be sold due to numerous requests from the city for house construction.

Suplit Stone Size Type. Mountain stone is generally called batu glondongan (boulder), these stones are to be broken into pieces/chunks. The stones are originated from mountains surrounding Moramo. These batu glondongan are then broken into suplit stones in various sizes. Women workers broke the suplit stones into various sizes, ranging from the size of $2 \times 1$ $\mathrm{cm}, 2 \times 3 \mathrm{~cm}, 3 \times 5 \mathrm{~cm}$ and $5 \times 7 \mathrm{~cm}$ size. Most of these workers produce $2 \times 1 \mathrm{~cm}$ suplit stones as there's high demand for that particular size to be used in casting. There are also demands for other sizes, but most were conducted through specified orders.

Suplit Sale System. Batu glondongan were broken into suplit stone chunks then sold to businessman trucks coming to buy stones. Stone owner negotiated a sale price of stone per truck. After the price was agreed on, then the owner of the truck immediately hire labors to load the suplit stones into the trucks. Labor wages or salaries (separate from wages from breaking stones) for loading each truck is about IDR 50,000 to IDR 80.000.

Statement Supporting the Family Economic Life. According to interviews with workers (December $12^{\text {th }}, 2016$ ) states that what they are doing now is very supportive of their family life. Working as stone crushers helped them in fulfilling children needs. The economy issue in the family has been solved as they obtain daily income from producing suplit stones. 


\section{CONCLUSION}

Based on the research result, socioeconomic level of women suplit stone breaker is still relatively low; it was studied in several aspects pertaining to the socio-economic conditions. The level of education is relatively low, they generally went to primary/elementary school education or never received any form of education. They managed to produce 4 to 10 arco of suplit stone per worker. Revenue received by workers on average is IDR 30,000 per day. Working as stone crushers has negative impact on eye and breathing. Women workers were mostly housewives who help their husbands and families to supplement the household income to support the family's economic life.

These women work as stone crushers due to lack of capital to conduct business. The negative impact is health hazard on eye and breathing. The desired expectations are in the form of assistance from other parties, such as government or employers in the form of working capital, equipment, and labor, as well as safety equipment such as masks and eye protection.

Income received by the workers used to meet basic daily needs in the form of food and other type daily needs. Therefore basic needs could be fulfilled using income received in daily work. Workers stated suplit stone crushers occupation is very helpful and capable to support family economy.

\section{REFERENCES}

1. De Soto, H. 1992. Still No Other Way: Hidden Revolution in the Third World. Obor Indonesia. Jakarta.

2. Effendi, TN 1993. Human Resources Employment Opportunities and Poverty. PT. Tiara discourse Yogya. Yogyakarta.

3. Hart, K. "Informal Income Opportunities and Urban Employmentin Ghana". In Manning, C. and Effendi, TN 1991. Urbanization, Unemployment, and the Informal Sector in the City, Obor Indonesia, Jakarta.

4. Hidayat. 1978. "Development of the Informal Sector in National Development: Problems and Prospects". In Effendi, T.N.Human Resources Employment Opportunities andPoverty. PT. Tiara Discourse Yogya. Yogyakarta.

5. Hugo, GJ "Participation of Migrants in Urban Economies in West Java". In Manning and Effendi.1991.Urbanization, unemployment, and the Informal Sector in thecity.Obor Indonesia. Jakarta.

6. Lewis, A, "Economic Development With Unlimited Supplies of Labor". In Rachbini and Hamid. 1994. Urban Informal Economy: Symptoms involution Second Wave. PT. Reader LP3ES. Jakarta.

7. Mabogunje, AL 1991. A New Paradigm for UrbanDevelopmnet.In Summers. LH and Shirvan (ed). Procedding of the World Bank, Annual Confrence on Development Review and the World Bank Research Observer.

8. Manning, C. 1980. "Segmentasi Pasar Tenaga Kerja di Sektor Industri di Jawa". Dalam Effendi, TN 1993. Sumber Daya Manusia Peluang Kerja dan Kemiskinan. PT. Tiara Wacana Yogya. Yogyakarta.

9. , 1981. "Penyerapan Tenaga Kerja Di Indonesia : Jawa dan luar Jawa dan Implikasi untuk Sumatera Selatan”. Kertas Kerja Tidak Diterbitkan. Dalam Effendi, TN 1993. Sumber Daya Manusia Peluang Kerja dan Kemiskinan. PT. Tiara wacana Yogya. Yogyakarta.

10. Manning, C dan Effendi, TN 1991. Urbanisasi, Pengangguran, dan Sektor Informal di Kota. Yayaysan Obor Indonesia. Jakarta.

11. Mappangaja, AN 1991. Pedagang Kaki Lima Dalam Prospek pembangunan Kota Madya Ujung Pandang (tesis). Program Pascasarjana Universitas hasanuddin. Ujung Pandang.

12. Mazumdar, D. 1976. "The Urban Informal Sector". Dalam Effendi, TN 1993. Sumber daya Manusia Peluang Kerja dan Kemiskinan. PT. Tiara Wacana Yogya. Yogyakarta. 
13. McGee, TG "Perombakan Struktural dan Kota di Dunia Ketiga : Suatu Teori Involusi Kota". Dalam Manning dan Effendi, TN 1991. Urbanisasi, Pengangguran, dan sektor Informal di Kota. Yayasan Obor Indonesia. Jakarta.

14. Nasution, MZ 1988. Sektor Informal di Perkotaan. Pusat Antar Universitas, Stusi Sosial. Yogyakarta.

15. Nurul Widyaningrum Resmi Setia, 2011. Usaha Kecil dan Sektor Informal. http://akatiga.org/index.php/penelitian/usaha-kecil/107-topik-penelitian-usaha-kecil

16. Pembangunan Ekonomi Daerah Sektor Informal (Hasil Penelitian 2011). http://bappeda.pontianakkota.go.id/dok/BAB\%20II\%20Kajian\%20PKL.pdf

17. Rachbini, DJ dan Hamid, A. 1994. Ekonomi Informal Perkotaan: Gejala Involusi Gelombang Kedua. PT. Pustaka LP3ES. Jakarta.

18. Sethuraman, SV 1985. "Informal Sector In Indonesia: An Assesment Of Policies". Technical Report, WEP. ILO, Geneva. Dalam Rachbini, DJ dan Hamid, A. 1994. Ekonomi Informal Perkotaan : Gejala Involusi Gelombang Kedua. PT Pustaka LP3ES. Jakarta.

19. , 1991. "Sektor Informal di Negara Sedang Berkembang". Dalam Manning, C dan Effendi, TN Urbanisasi, Pengangguran, dan Sektor Informal di Kota. Yayasan Obor Indonesia. Jakarta. Squire, Lyn. 1986. Kebijaksanaan Kesempatan Kerja di Negeri-Negeri Sedang Berkembang: Sebuah Survei Masalah-masalah dan Bukti-bukti. University of Indonesia. Jakarta.

20. Strategi Pengembangan Sektor Informal Untuk Meningkatkan Pertumbuhan Ekonomi Daerah http://www.slideshare.net/suparmono/2-sektor-informal 